\section{Effects of Exogenous Gibberellic Acid in Huanglongbing-affected Sweet Orange Trees under Florida Conditions-II. Fruit Production and Tree Health}

\author{
Sukhdeep Singh, Taylor Livingston, Lisa Tang, and Tripti Vashisth \\ Citrus Research and Education Center, University of Florida/IFAS, 700 \\ Experiment Station Rd., Lake Alfred, FL 33850
}

Additional index words. abscission, canopy density, fruit size, oxidative stress, plant defense response, preharvest fruit drop, yield

\begin{abstract}
Fruit production of sweet orange (Citrus sinensis) in Florida has been declining with the presence of Huanglongbing [HLB; Candidatus Liberibacter asiaticus (CLas)] disease. Through disruption of the balance of endogenous hormone levels, the disease has negative impacts on fruit development, mature fruit retention, and overall tree health. Thus, the goal of this research was to determine whether plant growth regulator gibberellic acid $\left(\mathrm{GA}_{3}\right)$ can be used to improve the production issues caused by HLB. For 'Valencia' sweet orange, although foliar applied $\mathrm{GA}_{3}$ from September to January (33 $\mathrm{mg} \cdot \mathrm{L}^{-1}$ for five applications) resulted in $50 \%$ decrease in bloom the following spring (results presented in Tang et al., 2021), this treatment did not cause reduction in yield of current and subsequent crops. Moreover, a $30 \%$ average increase in yield in $\mathbf{G A}_{3}$-treated trees was observed over a period of 4 years. The size of mature fruit was also increased (by $4 \%$ to $5 \%$ ) with reduced fruit drop rate near harvest in $\mathbf{G A}_{3}$-treated trees compared with nontreated control trees. Furthermore, the canopy density, an indicator of HLB severity, was maintained in trees applied with $\mathrm{GA}_{3}$ (from $\mathbf{9 0 . 8 \%}$ light interception to $\mathbf{9 0 . 4 \%}$ ). In contrast, there was a substantial decrease in canopy density for control trees (from $91.6 \%$ to $84.0 \%$ ). Gene expression analysis of abscission zone and leaves indicated that $\mathrm{GA}_{3}$-treated trees had enhanced oxidative stress mitigation mechanism and plant defense response. Given that there is no cure for $\mathrm{HLB}$, these results presented a possible remedy of using $\mathrm{GA}_{3}$ in sustaining tree health for field-grown sweet orange affected by HLB.
\end{abstract}

Huanglongbing (HLB), a devastating citrus disease (Citrus sp.), was discovered in Florida in 2005 and is now present in almost all citrus-producing counties of Florida (Gottwald, 2010). As a result, citrus production has gradually decreased in Florida, causing substantial financial losses to the citrus industry (Spreen et al., 2014). This disease is caused by a phloem-limited bacterium known

Received for publication 30 Sept. 2021. Accepted for publication 1 Dec. 2021.

Published online 25 January 2022.

We thank Marissa Caspari and Wesley S. Webb for the technical assistance in field-related activities. This work was funded by Citrus Initiative, funded by Florida Legislature. Mention of trade names or commercial products in this publication is solely for the purpose of providing specific information and does not imply recommendation or endorsement by the U.S. Department of Agriculture.

Current affiliation for L.T.: U.S. Department of Agriculture, Agricultural Research Service, Appalachian Fruit Research Station, Agricultural Research Service, Kearneysville, WV 25430.

T.V. is the corresponding author. E-mail: tvashisth@ufl.edu.

This is an open access article distributed under the CC BY-NC-ND license (https://creativecommons. org/licenses/by-nc-nd/4.0/). as Candidatus Liberibacter asiaticus (CLas) and is transmitted by an insect vector, asian citrus psyllid (Diaphorina citri Kuwayama) (Bove, 2006). Infection of CLas causes a in limited nutrient and water uptake (Graham et al., 2013; Hamido et al., 2017; Johnson et al., 2014). Disease-affected citrus trees subsequently develop leaf blotchy mottle and exhibit significant leaf drop and twig dieback, leading to a dramatic reduction in canopy density within a short time (Bove, 2006). Fruit of the diseased trees are typically small in size with poor juice quality (Baldwin et al., 2010). Furthermore, high preharvest fruit drop has been reported in sweet orange trees affected by HLB (Albrigo and Stover, 2015; Tang et al., 2019). This preharvest drop, in addition to the rapid decline of trees (Bassanezi et al., 2011), has resulted in a high reduction in citrus yield. As HLB has become an epidemic in Florida, the rate of preharvest fruit drop in sweet orange (Citrus sinensis) has risen from $12 \%$ in $2005-06$ to $26 \%$ in 2018-19 (USDA, 2019). Under field conditions, 'Valencia' and 'Hamlin' sweet orange trees with severe HLB symptoms had significantly higher preharvest fruit drop than severe loss of feeder roots in trees, resulting mildly symptomatic trees (Tang et al., 2019, 2020), indicating a correlation between preharvest fruit drop and HLB severity. There is currently no cure for the HLB disease; therefore, developing strategies to reduce preharvest fruit drop and improve yield could mitigate yield loss in HLB-affected trees.

Preharvest fruit drop is the abscission of physiologically mature fruit (at stage III of fruit development) that occurs 3 to 4 months before harvest (Ferguson and Grafton-Cardwell, 2014; Iglesias et al., 2007). Abscission is the physiological process of cell separation in plants controlled by endogenous hormones at the abscission zone (AZ) (Estornell et al., 2013; Patterson, 2001). Ethylene is the primary hormone that initiates abscission, whereas auxin and gibberellins (GA) counteracts the effect of ethylene on abscission (Patterson, 2001). Exogenously applied ethylene upregulated the expression of genes involved in fruit abscission at the calyx AZ (AZ-C) in citrus (Estornell et al., 2013). Additionally, the positive role of jasmonic acid (JA) in abscission has been demonstrated in many plants including citrus (Kim, 2014; Miyamoto et al., 1997). Several studies have shown alteration of plant hormones in the leaf and fruit of HLB-affected citrus (Martinelli et al., 2012; Nehela et al., 2018; Zhao et al., 2019), raising the possibility that HLB-induced changes in hormone balance may play a role in increased preharvest fruit drop. Genes related to ethylene and JA synthesis and signaling were upregulated in AZ-C of dropped fruit from HLB-diseased trees compared with attached fruit in 'Hamlin' sweet orange (Zhao et al., 2019). Furthermore, genes involved in auxin and gibberellic acid biosynthesis were downregulated, whereas ethylene production and signal transduction were upregulated in AZ-C of HLB-susceptible 'Hamlin' sweet orange compared with HLB-tolerant 'LB8-9' mandarin hybrid \{'Clementine' mandarin (C. reticulata) and 'Minneola' tangelo ['Duncan' grapefruit (C. paradisi) and 'Dancy' tangerine (C. reticulata $)]$, which had a higher and lower preharvest fruit drop rate, respectively (Tang and Vashisth, 2020). Given the differences in susceptibility of the two citruses, the results suggest a correlation between HLB-triggered changes in endogenous hormone homeostasis and increased mature fruit abscission.

Gibberellic acid $\left(\mathrm{GA}_{3}\right)$ positively regulates fruit growth by causing a significant increase in cell division and expansion (Sachs et al., 1959). Applications of $\mathrm{GA}_{3}$ during stage I of fruit development reduced immature fruitlet abscission and increased fruit size in 'Clementine' mandarin (García-Martínez and GarcíaPapí, 1979). Exogenous $\mathrm{GA}_{3}$ enhanced fruitlet retention in healthy 'Valencia' sweet orange trees when applied during fruit set (Chen et al., 2006). When $\mathrm{GA}_{3}$ was sprayed in combination with antibiotics and foliar fertilizer, the yield of HLB-affected Clementine mandarin increased, and disease severity decreased (Shokrollah et al., 2011). Gibberellic acid is also known to inhibit senescence and abscission; $\mathrm{GA}_{3}$ applications delayed peel senescence and extended 
the sweet orange harvest season (Estornell et al., 2013). Cross talk between $\mathrm{GA}_{3}$ and other endogenous plant hormones such as salicylic acid (SA), JA, ethylene, and auxins have been observed (Alonso-Ramírez et al., 2009; Martinelli et al., 2013; Navarro et al., 2008), where GA inhibits ethylene and JA signaling. Exogenous $\mathrm{GA}_{3}$ has been used successfully to control preharvest fruit drop in healthy citrus (Ferguson and Grafton-Cardwell, 2014). Still, no consistent effect of $\mathrm{GA}_{3}$ has been reported on HLBassociated preharvest fruit drop in sweet orange when applied once during the preharvest period (stage III of fruit development) (Albrigo and Stover, 2015). Notably, recent studies on preharvest fruit drop suggest that the events leading to preharvest fruit drop occur weeks (if not months) before the physical fruit drop is evident (Tang et al., 2019, 2020). Prolonged and offseason flowering, commonly observed in HLBaffected trees under Florida conditions (Tang et al., 2021), is also speculated to contribute to fruit drop. Exogenously applied $\mathrm{GA}_{3}$ has been reported to suppress flowering in citrus (Goldberg-Moeller et al., 2013; Lord and Eckard, 1987; Muñoz-Fambuena et al., 2012) and was demonstrated to shorten spring bloom as well as reduce flowering intensity by $50 \%$ when applied in preceding fall (monthly from September through January) at $49 \mathrm{~g} \cdot \mathrm{ha}^{-1}$ (33 $\left.\mathrm{mg} \cdot \mathrm{L}^{-1}\right)$ in HLB-affected 'Valencia' sweet orange (Tang et al., 2021).

The presented work describes the efficacy of foliar $\mathrm{GA}_{3}$ in improving fruit yield by manipulating flowering, fruit growth, and plant defense response in 'Valencia' sweet orange affected by HLB. The presented work began as a flowering suppression study, reported in Tang et al. (2021). Surprisingly, we found that although five monthly applications of $\mathrm{GA}_{3}$ at $49 \mathrm{~g} \cdot \mathrm{ha}^{-1}$ reduced total flowering by half, the resulting fruit yield remained statistically unaffected (in fact, numerically higher) in the first year after application in $\mathrm{GA}_{3}$-treated trees compared with untreated trees. Hence, an objective to determine $\mathrm{GA}_{3}$ effects on fruit growth, preharvest drop, and tree productivity was added to the ongoing field trial. This article presents data on fruit yield, fruit size, fruit drop, and plant defense-related gene expression in $\mathrm{GA}_{3}$-treated trees. The trial reported in Tang et al. (2021) originally included six $\mathrm{GA}_{3}$ treatments (with various rates and application times); however, this work focuses on the impacts of the most intense $\mathrm{GA}_{3}$ application treatment $\left(33 \mathrm{mg} \cdot \mathrm{L}^{-1}\right.$ or $49 \mathrm{~g} \cdot \mathrm{ha}^{-1}$, applied five times), where the highest flower suppression was observed (Tang et al., 2021), compared with control.

\section{Materials and Methods}

Plant materials and gibberellic acid treatments. Eight-year-old 'Valencia' sweet orange on 'Swingle' citrumelo (C. paradisi $\times$ Poncirus trifoliata) rootstock trees in a commercial grove in central Florida, Fort Meade, were selected for this experiment. The grove was maintained under standard grove management practices that included fertilization and pest and disease management. The trees used in this experiment exhibited moderate HLB symptoms but were uniform in size. The experiment was set up as a completely randomized block design with four replicates where three trees were considered as one experimental unit. Each block (replication) included one untreated control and $\mathrm{GA}_{3}$ treatment. For the treatment, exogenous $\mathrm{GA}_{3}$ at $49 \mathrm{~g} \cdot \mathrm{ha}^{-1}\left(\approx 33 \mathrm{mg} \cdot \mathrm{L}^{-1}\right.$ or $20 \mathrm{~g} /$ acre) (ProGibb LV Plus; Valent BioSciences, Libertyville, IL) containing $0.05 \%(\mathrm{v} / \mathrm{v})$ nonionic surfactant (Induce; Helena Chemical, Collierville, TN) was applied monthly from September to January (five applications). For the ease of understanding, exogenous $\mathrm{GA}_{3}$ used in the treatment and $\mathrm{GA}_{3}$-treated trees are respectively referred to as "GA" and "GA trees" from this point forward in this report. The control trees were sprayed with an equal amount of water containing surfactant as the GA treatment. All foliar applications were uniformly distributed to the canopy to the point of runoff $(\approx 4.7 \mathrm{~L} /$ tree) using a skid sprayer (Chemical Containers, Lake Wales, FL). The experiment was conducted on the same trees for five consecutive years (2016-17, 2017-18, 2018-19, 2019-20, and 2020-21) where GA applications were made in September through January and fruit were harvested in March to May, depending on fruit maturity and grower management. It should be noted that GA applications in this study affected flower induction period as well as fruit development period. Take the crop harvested in Spring 2018, for example, GA sprays in 2016-17 suppressed flowering in 2017, the resulting crop received another set of GA sprays during fruit development (from Sept. 2017 to Jan. 2018) and then harvested in Spring 2018.

Total yield, fruit size, and preharvest fruit drop. Trees were hand harvested when the fruit reached commercial maturity standards based on ratio of total soluble solids (TSS) and titratable acidity (TA) using pocket refractometer (Atago USA, Inc., Bellevue, WA). Total harvested fruit from each tree were weighed (expressed as $\mathrm{kg} /$ tree). Trees of both treatments were evaluated for yield in all 5 years, however, fruit size was measured for 4 years (2017-18, 2018-19, 2019-20, and 2020-21). Preharvest fruit drop rate was quantified for 3 years (2018-19, 2019-20, and 2020-21). In addition, in the 2018-19 experiment, fruit detachment force (FDF; an indicator of how tightly and loosely fruit are attached to tree branches) measurement and detailed gene expression analysis (discussed in the next section) were performed. The reason for staggered data collection is that this trial was overlaid on an ongoing study of flower manipulation using GA. With 2017-18 harvest data, it was discovered that sweet orange trees of GA treatment were performing better in fruit production than control trees; therefore, additional parameters were assessed in 2018-19 as follows.

From the harvested fruit, 20 fruit (as an experimental unit) were randomly selected from all trees to measure fruit diameter. Fruit diameter was measured using vernier caliper and expressed in millimeters $(\mathrm{mm})$ to represent fruit size. Fruit detachment force, which determines the force required to separate the fruit from the branch, an indicator of likeliness of fruit to drop (Tang et al., 2019), was measured on 20 randomly chosen mature fruit that were still attached to control and GA trees in May 2019 with a digital force gauge (Force One, Wagner Instruments, Greenwich, CT), expressed in kilogram-force (kgf). For preharvest fruit drop rate, dropped fruit (on the ground) from all trees were counted biweekly throughout the preharvest period (from September through harvest in April or May). The rate of preharvest fruit drop was expressed as the percentage of the total dropped fruit from September to harvest out of the total fruit number (number of fruit at harvest + total number of dropped fruit).

Canopy density. HLB-affected trees often have sparse canopies as a result of shoot dieback; therefore, canopy density is a good indicator of tree health and growth. Canopy density was estimated using photosynthetically active radiation $(P A R)$ interception $(\% \mathrm{INT})$ by the canopy A plant canopy imager (CI-110; CID Bio-Science, Camas, WA) was used to measure $P A R$ outside the canopy ( $P A R_{\text {outside; }}$; without any blockage of sunlight) and underneath the canopy $\left(P A R_{\text {inside; }}\right.$ average of the $P A R$ of four quadrants of the canopy at $\approx 15$ $\mathrm{cm}$ height from the ground) at solar noon. The $\%$ INT was calculated by:

$$
\left[\left(P A R_{\text {outside }}-P A R_{\text {inside }}\right) / P A R_{\text {outside }}\right] \times 100
$$

Relative gene expression analysis. Gene expression analysis was performed on the leaves and fruit AZ-C from the control and GA trees during the 2018-19 experiment. Mature, fully expanded leaves were collected from the trees on 13 Dec. 2018 (after three applications of GA, at approximately the end of stage II of fruit development and before beginning of fruit drop period). Tissues of AZ-C, where HLBassociated fruit abscission takes place, were collected from five mature fruit that were on the tree at time of harvest (May 2019). After collection, leaves and AZ-C were immediately frozen in liquid nitrogen and stored at $-80^{\circ} \mathrm{C}$ until further use. Commercial extraction kits (RNeasy Plant Mini Kit; Qiagen, Hilden, Germany and Invitrogen PureLink RNA Mini Kit; Thermo Fisher Scientific, Waltham, MA) were used as per the manufacturer's instructions for total RNA extraction from AZ-C and leaves, respectively. The RNA quantity and quality were determined by spectrophotometer (Epoch 2 Microplate; BioTek Instruments, Winooski, VT) and denaturing formaldehyde $1.2 \%$ agarose gels (Rio, 2015), respectively. Subsequently, cDNA synthesis was carried out using $1 \mu \mathrm{g}$ of RNA treated with RQ1 RNase-Free DNase (Promega, Madison, WI). The DNasetreated RNA was used for reverse transcription using oligo $(\mathrm{dT})_{15}$ primer, dNTP mix, and ImProm-II reverse transcriptase (Promega) in a $20-\mu \mathrm{L}$ reaction in a thermocycler $(\mathrm{C} 1000$ Touch Thermal Cycler; Bio-Rad, Hercules, CA) according to the manufacturer's protocol.

Relative expression of 24 and 22 genes in AZ-C and leaves, respectively, related to phytohormone signaling, carbohydrate metabolism, 
plant defense response, and oxidative stress was determined using real-time quantitative polymerase chain reaction (qRT-PCR). The primer sequences for specific genes were designed using Primer BLAST (NCBI; https:// www.ncbi.nlm.nih.gov/tools/primer-blast) and are listed in Supplemental Table 1. Ten microliters of qPCR reactions containing $2 \mu \mathrm{L}$ of diluted cDNA, $3 \mu \mathrm{L}$ forward and reverse primer mix $(0.3 \mu \mathrm{M})$, and $5 \mu \mathrm{L}$ of PowerUp SYBR Green Master Mix (2×) (Applied Biosystems; Foster City, CA) were carried out in a 7500 Fast real-time PCR system (Applied Biosystems). Each reaction was run first at $50^{\circ} \mathrm{C}$ for $2 \mathrm{~min}$, then $95^{\circ} \mathrm{C}$ for $10 \mathrm{~min}$, followed by 40 cycles of $95^{\circ} \mathrm{C}$ for $15 \mathrm{~s}$ and $60^{\circ} \mathrm{C}$ for $60 \mathrm{~s}$. Dissociation-curve ranging from 60 to $95^{\circ} \mathrm{C}$ was analyzed at the end of each qPCR to confirm that nonspecific products were not formed. The relative expression level (fold change) of genes were calculated using the quantification cycle $(\mathrm{Ct})$ by Pfaffl method (Hellemans et al., 2007; Pfaffl, 2001) with actin 7 and $\operatorname{dim} 1$ as the reference genes (Mafra et al., 2012), the comparison were made in GA-treated samples against untreated samples.

Statistical analysis. The statistical analysis was conducted in R (R Core Team, 2018). Repeated measures analysis of variance with family error of 0.1 was used to evaluate the effect of treatment on yield, fruit size, and preharvest fruit drop rate from 2017-18 to 2020-21. Student's $t$ test, with family error of 0.1 , was used to determine the significant effects of the GA in comparison with untreated control on FDF, and canopy density; however, 0.05 cutoff was used for gene expression in AZ-C and leaves. Family error of 0.1 was used for all the field component of this study as CLas-infected trees generally show a large tree to tree variability, possibly due to different levels of infection within each tree (even if the trees look similar in health).

\section{Results}

Total yield, fruit size, and preharvest fruit drop. Table 1 shows total yield of control and GA-treated trees in each year from 2017-18 to 2020-21. The yield data of 2016-17 crop (developing from bloom in 2016) were not included herein as the GA treatment (from Sept. 2016 to Jan. 2017) was implemented after the flowering, fruit set, and initial fruit growth in 2016 and therefore did not affect those reproductive steps that resulted in the 2016-17 crop, whereas GA treatment in all other years impacted the crop from the flowering time. In 2017-18, the first year after GA treatment in 2016-17 that reduced flowering in Spring 2017, yield of GA trees was $20 \%$ higher than untreated trees, despite not being statistically significant $(P=0.15)$. In 2018-19, 2019-20, and 2020-21, yield from GA trees was significantly higher yield than the control (by $35 \%, 27 \%$, and $42 \%$, respectively) $(P<0.1)$. On average, GA trees produced a $29 \%$ higher yield in four years than the control trees $(P=0.06$; Fig. 1$)$.

For 3 out of 4 years, 2017-18, 2018-19, and 2019-20, the size of fruit from GA trees
Table 1. Average fruit yield and fruit size for untreated and gibberellic acid $\left(\mathrm{GA}_{3}\right)$ treated Huanglongbing-affected 'Valencia' sweet orange for 4 consecutive years in 2017-18, 2018-19, 2019-20, and 2020-21.

\begin{tabular}{lcccc}
\hline Treatment & $2017-18$ & $2018-19$ & $2019-20$ & $2020-21$ \\
\hline & \multicolumn{4}{c}{ Fruit yield $(\mathrm{kg} /$ tree $)$ per year ${ }^{\mathrm{z}}$} \\
\cline { 2 - 5 } Control & $97 \pm 15$ & $95 \pm 13 \mathrm{~b}$ & $74 \pm 15 \mathrm{~b}$ & $54 \pm 21 \mathrm{~b}$ \\
GA $^{\mathrm{y}}$ & $116 \pm 16$ & $128 \pm 7 \mathrm{a}$ & $94 \pm 8 \mathrm{a}$ & $77 \pm 5 \mathrm{a}$ \\
$P$ value & 0.15 & 0.02 & 0.10 & 0.07 \\
& \multicolumn{4}{c}{ Fruit size $(\mathrm{mm})$} \\
Control & $66 \pm 2 \mathrm{~b}$ & $66 \pm 1 \mathrm{~b}$ & $66 \pm 2 \mathrm{~b}$ & $67 \pm 4$ \\
GA & $69 \pm 1 \mathrm{a}$ & $68 \pm 3 \mathrm{a}$ & $69 \pm 2 \mathrm{a}$ & $67 \pm 2$ \\
$P$ value & $<0.001$ & $<0.001$ & $<0.001$ & 0.15 \\
\hline
\end{tabular}

${ }^{\mathrm{z}}$ Within a column, means followed by different letters are significantly different $(P<0.1)$

${ }^{\mathrm{y}}$ Gibberellic acid applied at $49 \mathrm{~g} \cdot \mathrm{ha}^{-1}$ monthly from September to January of each year with first application in 2016 . was significantly greater $(69,68$, and $68 \mathrm{~mm}$, respectively) compared with the control trees $(66,66$, and $66 \mathrm{~mm}$, respectively) (Table 1). In 2021, no difference in fruit size was observed between two treatments; however, the total fruit number was higher in GA trees than in control (425 compared with 287 per tree). In other years, the number of fruit was not significantly different between control and GA tress (data not shown).

In all 3 years when preharvest fruit drop was measured, GA tree consistently showed numerically lower preharvest fruit drop rate than control trees (Fig. 2). However, no significant difference in fruit drop rate was observed in 2019 and 2021. In 2020, GA trees had $23 \%$ fruit drop, which was significantly lower $(P=0.06)$ than the fruit drop rate in control $(30 \%)$.

Fruit from GA trees had a significantly higher FDF value $(6.3 \mathrm{kgf})$ than fruit from control trees $(5.3 \mathrm{kgf})(P=0.01)$. Additionally, FDF was significantly and positively correlated with fruit size $(\mathrm{r}=0.41, P<$ 0.0001 ), indicating that larger fruit had higher FDF and thus a lower tendency to drop, compared with small fruit.

Canopy density. Canopy density was measured for two consecutive years, 2019 and
2020 (Fig. 3). In 2019, the PAR interception was not different between control $(91.6 \%)$ and GA $(90.8 \%)$ trees. However, in 2020, control trees had lower canopy density than GA-treated trees $(P=0.08)$; an $8 \%$ decrease in PAR interception for control trees (84\%) was observed compared with GA trees (90.4\%). The decline in canopy density was significant for control trees, whereas GA trees remained unchanged.

Relative gene expression in AZ-C. In May 2019 (harvest time), the expression levels of three out of 24 genes differed in the AZ-C of the GA fruit compared with the control fruit (Table 2; Supplemental Table 2). One out of three GA biosynthesis genes, gibberellin 3-beta-dioxygenase 1 (GA3oxl) was expressed in the AZ-C of control trees; its expression was below the limit of detection for the GA trees. When AZ-C of GA trees were compared with the controls, the expression levels of linoleate 13s-lipoxygenase 2 (LOX2), a gene involved in JA synthesis was significantly lower. The transcript levels of oxidative stress-related genes respiratory burst oxidase homolog $(R b o h)$ was 2-fold lower in GA trees than control trees. The expression of a phloem protein gene, phloem protein 2-b15 $(P P 2-B 15)$, was $\approx 10$-fold lower in GA trees

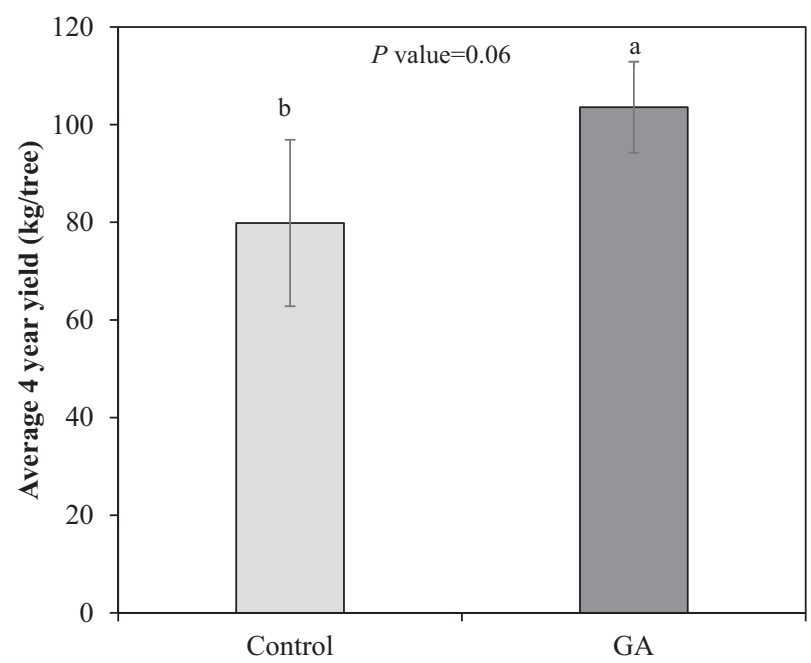

Fig. 1. Average yield of untreated and gibberellic acid $\left(\mathrm{GA}_{3}\right)$ treated Huanglongbing-affected 'Valencia' sweet orange over 4 years 2017-18, 2018-19, 2019-20, and 2020-21. GA 3 treatment included September to January monthly application at $49 \mathrm{~g} \cdot \mathrm{ha}^{-1}$ each year starting from Sept. 2016. Different letters indicate significant differences $(P<0.1)$ among treatments. 


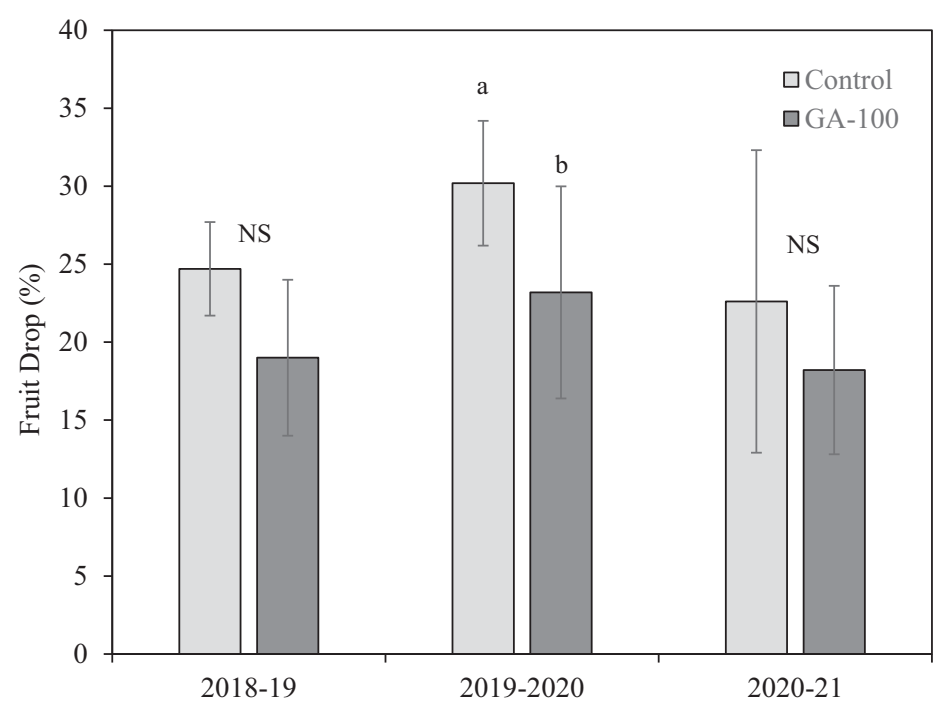

Fig. 2. Preharvest fruit drop rate of untreated and gibberellic acid $\left(\mathrm{GA}_{3}\right)$ treated Huanglongbingaffected 'Valencia' sweet orange for 2018-19, 2019-20, and 2020-21. GA 3 treatment included September to January monthly application at $49 \mathrm{~g} \cdot \mathrm{ha}^{-1}$ each year starting from Sept. 2016. Different letters indicate significant differences $(P<0.1)$ among treatments. NS $=$ not significantly different.

than in control despite not being statistically different between the two treatments.

Relative gene expression in leaves. The leaves of GA trees had significantly higher expression of photosystem-II 5-kDa protein (PSII5Kd), LOX2, and constitutive disease resistance (CDRI) compared with control (Table 3). Other genes that were not significantly different among the leaves of control and GA trees are presented in Supplemental Table 3.

\section{Discussion}

When GA was applied at $49 \mathrm{~g} \cdot \mathrm{ha}^{-1}$ monthly from September to January, HLBaffected 'Valencia' sweet orange trees had a greater yield than the untreated control. The

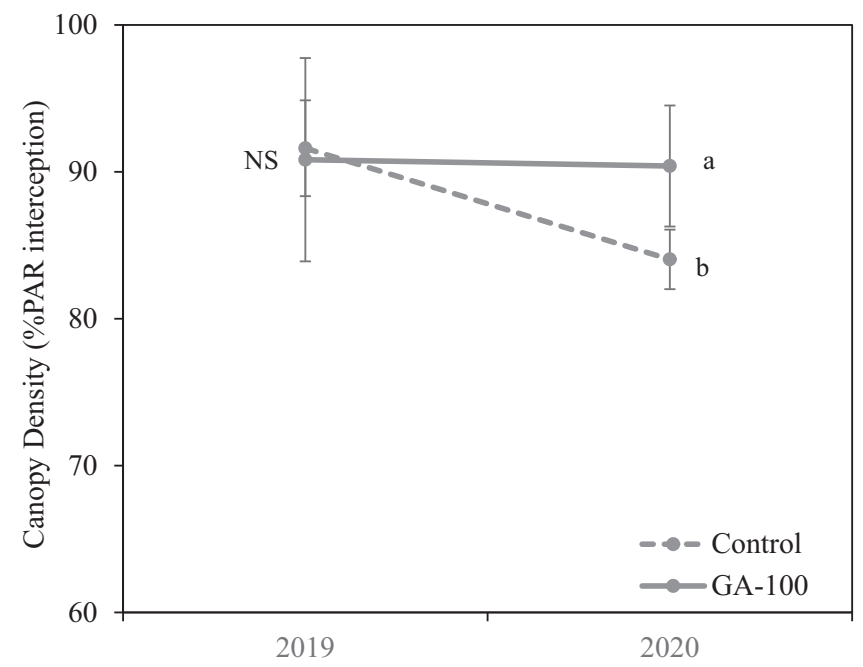

Fig. 3. Canopy density (expressed as photosynthetically active radiation interception) for untreated and gibberellic acid $\left(\mathrm{GA}_{3}\right)$ treated Huanglongbing-affected 'Valencia' sweet orange. $\mathrm{GA}_{3}$ treatment included September to January monthly application at $49 \mathrm{~g} \cdot \mathrm{ha}^{-1}$ each year starting from Sept. 2016. Different letters indicate significant differences $(P<0.1)$ among treatments within that year. NS = not significantly different. were harvested from GA-treated trees compared with control, suggesting the inverse relationship between the fruit size and fruit number (Guardiola and García-Luis, 2000).

Notably, in this research, the GA treatment resulted in a marked reduction in flower intensity by $\approx 50 \%$ in the following spring compared with control trees (Tang et al., 2021). Nevertheless, this decrease in bloom by GA did not reduce fruit number compared with the control trees at harvest but increased fruit size. Similarly, in 'Washington' navel sweet orange, the final number of fruit was unrelated to the number of flowers in response to GA spray in winter, which led to larger fruit than those of control (Guardiola et al., 1984). Sweet orange trees typically bloom profusely, and only a minimal number of flowers $(<1 \%)$ turn into harvestable fruit (Ferguson and Grafton-Cardwell, 2014). In other words, a significant amount of resources used for flower formation are lost during the production season due to flower and fruit abscission. Many citrus cultivars have demonstrated an inverse relationship between flower number and subsequent fruit size unrelated to crop load (Guardiola, 1988). This inverse relationship is a result of temporal sink competition between flower development and initial fruit development. Further, ovary size at anthesis is inversely related to flower number (Guardiola et al., 1984). A larger ovary size at anthesis, possibly the case for GA trees in this report because of the significantly reduced floral intensity, results in faster early fruitlet growth and an increase in final fruit size (Guardiola, 1988). In addition, GA application can increase leafy inflorescence (Lord and Eckard 1987; Tang and Lovatt, 2019). Citrus leafy inflorescence sets more fruit and develops better and larger fruit than leafless inflorescence (Jahn, 1973; Moss et al., 1972). Hence, it is possible that the ratio of leafy inflorescences, which produce larger apical flowers and fruit (Moss et al., 1972), to leafless inflorescences increase in response to GA thus resulting in better fruit growth and productivity.

In citrus, GA suppresses floral development by continuing the vegetative development of the shoot apical meristem when applied before buds become determined to flower formation (Lord and Eckard 1987). A number of studies have also reported enhanced vegetative shoot growth in response to GA applications (Goldberg-Moeller et al., 2013; Muñoz-Fambuena et al., 2012; Tang and Lovatt, 2020). Consistently, the result of this study demonstrates that the canopy density was maintained in GA trees, whereas there was a significant decrease in canopy density for untreated control trees. Shoot dieback is a classic HLB symptom (Bove, 2006). Even well managed HLB-affected trees undergo a persistent decline in canopy density because of branch dieback (Vashisth and Livingston, 2020). In HLB-affected sweet oranges, canopy density is positively correlated with fruit size, mature fruit retention, and overall yield (Tang et al., 2019, 2020). Briefly, trees with higher canopy density drop fewer fruit during the 
Table 2. Differentially expressed genes (expressed as log fold change) in fruit abscission zone of untreated and gibberellic acid $\left(\mathrm{GA}_{3}\right)$ treated Huanglongbing-affected 'Valencia' sweet orange at time of harvest, May 2019.

\begin{tabular}{llccc}
\hline Gene & \multicolumn{1}{c}{ Gene name } & Log FC control & Log FC GA & $P$ value \\
\hline GA3ox1 & Gibberellin 3-oxidase & $-4.657 \mathrm{a}$ & $-6.564 \mathrm{~b}$ & 0.04 \\
LOX2 & Linoleate 13S-lipoxygenase 2 & $-1.981 \mathrm{a}$ & $-2.928 \mathrm{~b}$ & 0.006 \\
Rboh & Respiratory burst oxidase homolog & $-0.2957 \mathrm{a}$ & $-0.584 \mathrm{~b}$ & 0.03 \\
\hline
\end{tabular}

${ }^{\mathrm{z}}$ Within a row, means followed by different letters are significantly different $(P<0.05)$.

${ }^{\mathrm{y}}$ Gibberellic acid applied at $49 \mathrm{~g} \cdot \mathrm{ha}^{-1}$ monthly from September to January of each year with first application in 2016 .

preharvest period, develop fruit with better size, and yield higher compared with those with a thin canopy due to substantial shoot dieback. Hence, improvement in canopy density can potentially improve the source-to-sink ratio, thus improving fruit growth, size, and overall tree productivity.

For commercial production in Florida, 'Valencia' sweet orange fruit remain on the tree for 12 to 16 months after fruit set in April. In the current study, GA applications (from September through January) overlapped the presumed stage II of fruit development, during which cell enlargement contributes to the rapid growth of fruit (Iglesias et al., 2007), of the fruit that developed from the flowers the previous spring. Relevantly, GA is known for its capacity to upregulate cell division and elongation, leading to organ expansion (Iqbal et al., 2011). In citrus, especially mandarin (C. reticulata), GA has been routinely used immediately after anthesis and early fruit development stages to improve fruit set and fruit size for better yield (Guardiola et al., 1984). HLBaffected trees produce small fruit (Rosales and Burns, 2011) and small fruit have been reported to undergo significant HLB-associated fruit drop (Tang et al., 2019, 2020). Supporting this observation, for the 3 years when the preharvest fruit drop rate was measured, GA trees consistently showed lower fruit drop than the control, with the values being significantly different between the two treatments in 2019-20. It should be noted that the cumulative drop rate for the untreated trees in 2018-19 and 2020-21 was relatively low (24\% and $23 \%$, respectively), leaving a minimal margin for substantial improvement by exogenous GA whereas in 2019-20, when the drop rate was higher than $30 \%$, a significant reduction in fruit drop in GA trees was observed. Generally, the HLB-associated fruit drop rate ranges from $30 \%$ to $80 \%$, depending on the disease severity (Tang et al., 2019, 2020). In addition to the significantly lower fruit drop rate in 2019-20, in 2018-19, at

Table 3. Differentially expressed gene (expressed as log fold change) of selected genes in leaves of untreated and gibberellic acid $\left(\mathrm{GA}_{3}\right)$ treated Huanglongbing-affected 'Valencia' sweet orange at end of stage II of fruit development (Dec. 2018).

\begin{tabular}{llccc}
\hline Gene & \multicolumn{1}{c}{ Gene name } & Log FC control $^{\mathrm{z}}$ & $\operatorname{Log~FC~GA}^{\mathrm{y}}$ & $P$ value \\
\hline LOX2 & Linoleate 13S-lipoxygenase 2 & $-0.068 \mathrm{a}$ & $-0.701 \mathrm{~b}$ & 0.01 \\
CDR1 & Aspartic proteinase constitutive disease resistance & $-0.135 \mathrm{~b}$ & $0.670 \mathrm{a}$ & 0.01 \\
PSII5kD & Photosystem II 5 k Da protein & $-0.074 \mathrm{~b}$ & $0.369 \mathrm{a}$ & 0.04 \\
\hline
\end{tabular}

${ }^{\mathrm{z}}$ Within a row, means followed by different letters are significantly different $(P<0.05)$.

${ }^{\mathrm{y}}$ Gibberellic acid applied at $49 \mathrm{~g} \cdot \mathrm{ha}^{-1}$ monthly from September to January of each year with first application in 2016. in Australia, one GA application 7 months after fruit set (stage II of fruit development) decreased preharvest fruit drop and extended the harvest window without affecting fruit quality (El-Zeftawi, 1980).

The favorable role of exogenously applied GA in reducing preharvest fruit drop is further supported by the gene expression analysis in the AZ-C. At the time of collection (at harvest), the expression level of gene involved in the biosynthesis of JA, $L O X 2$ was significantly lower in GA trees than in controls. The result is consistent with the reports in arabidopsis (Arabidopsis thaliana), in which exogenously applied GA suppressed the production of JA (Alonso-Ramírez et al., 2009; Navarro et al., 2008). Jasmonic acid and MeJA, members of jasmonate, promote abscission by either upregulating ethylene production or directly activating cell wall modification of AZ independent of ethylene (Miyamoto et al., 1997). In healthy 'Valencia' and 'Hamlin' sweet orange, MeJA treatment reduced FDF and increased fruit drop, accompanied by an increase in ethylene production in the fruit (Hartmond et al., 2000).

In HLB-affected citrus, JA accumulation and upregulation of its biosynthesis are triggered by psyllid feeding and CLas infection (Fu et al., 2016; Killiny and Nehela, 2017). Therefore, the downregulation of AZ-C LOX2 expression and leaf $L O X 2$ expression in GA trees compared with control suggests the alleviation of stress, likely brought about by CLas, in response to exogenous GA. Consistently, the expression of Rboh was lower in GAtreated trees. Rboh is a gene involved in the production of reactive oxygen species (ROS), Rboh transcript in the leaves of 'Valencia' sweet orange has been shown to increase upon CLas infection (Pitino et al., 2017). Additionally, genes related to oxidative stress responses were upregulated in AZ-C of HLB-susceptible 'Hamlin' sweet orange prone to preharvest drop in comparison with HLB-tolerant 'LB89' mandarin hybrid that had a low tendency to fruit drop (Tang and Vashisth, 2020), providing evidence that mature fruit abscission increases with the internal oxidative stress level in relation to the intrinsic susceptibility of trees to HLB. Thus, it suggests that the GA treatment delayed mature fruit abscission by downregulating the production of JA in the AZ-C and potentially mitigating the oxidative stress caused by HLB, thereby increasing fruit retention near harvest.

The higher expression of $C D R 1$ in leaves of GA trees than untreated control suggests that plant defense to the disease was enhanced by GA application. Similarly, compared with HLB-susceptible sweet orange, HLB-tolerant 'US-897' trifoliate orange hybrid ['Cleopatra' mandarin (C. reticulata) and 'Flying Dragon' trifoliate orange $(P$. trifoliata) $]$ has significantly greater expression of CDRl (Albrecht and Bowman, 2008). CDRl is involved in salicylic-acid-dependent inducible resistance responses and enhances resistance to bacterial pathogens in arabidopsis (Xia et al., 2004).

Given that HLB reduces photosynthetic activity and makes photosynthates less available 
to sinks, genes related to photosynthesis, such as PSII5kD, were downregulated in citrus trees infected with CLas (Albrecht and Bowman, 2008). In this study, leaves from GA trees had higher expression of PSII5kD than control leaves, indicating the potential for improved photosynthetic activity in GA trees compared with control trees.

Altogether, the results of gene expression analysis of leaves and AZ-C suggest improved hormonal balance, plant defense response, and photosynthesis in GA trees compared with control trees, therefore contributing to better tree vitality, indicated by the canopy density, and fruit production for 'Valencia' sweet orange in the presence of HLB.

The expression of GA3oxl, which encode key enzyme in GA biosynthesis pathways (Hedden and Phillips, 2000; Phillips et al., 1995), was not detected in the AZ-C of GA trees but was expressed in control. However, the other two GA biosynthesis genes in AZ-C and another gene in leaves were not differentially expressed among untreated and GAtreated trees; therefore, GA biosynthesis and metabolism in HLB-affected trees in response to exogenous GA application awaits further investigation.

\section{Conclusions}

Overall, the results presented herein suggest a beneficial effect of exogenously applied GA on HLB-affected trees. The GA applications seem to have a multipronged benefit for HLB-affected 'Valencia' sweet orange trees, through which a significant improvement in yield is achieved. First, GA treatment manipulates flowering, reducing the flowering intensity (analogous to flower thinning, which reserves tree resources for other developmental processes) and promoting leafy inflorescence; second, GA treatment increases vegetative shoot development to negate branch dieback caused by HLB, thereby sustaining the canopy vigor and possibly improving the source-to-sink ratio. Third, GA application on developing fruit improves fruit size and fruit retention. Finally, we provide evidence that GA application can improve plant defense responses and reduce oxidative stress.

Although GA treatment cannot eradicate the pathogen that causes HLB in citrus trees, the results of this study demonstrated that it could provide growers an alternative remedy to ameliorate the production issues that are associated with the disease, including yield decline, reduced fruit size, increased preharvest fruit drop, and rapid tree health decline, until a cure for HLB or complete HLB-resistant cultivars can be developed. In light of recent findings depicting the relationship between fruit development and fruit drop (Tang et al., 2020), fruit drop mitigation strategies with the use of plant growth regulators, including GA, must focus on the fruit development period.

\section{Literature Cited}

Albrecht, U. and K.D. Bowman. 2008. Gene expression in Citrus sinensis (L.) Osbeck following infection with the bacterial pathogen Candidatus Liberibacter asiaticus causing Huanglongbing in Florida. Plant Sci. 175:291-306, https://doi.org/ 10.1016/j.plantsci.2008.05.001

Albrigo, L.G. and E.W. Stover. 2015. Effect of plant growth regulators and fungicides on Huanglongbing-related preharvest fruit drop of citrus. HortTechnology 25:785-790, https://doi. org/10.21273/HORTTECH.25.6.785.

Alonso-Ramírez, A., D. Rodríguez, D. Reyes, J.A. Jiménez, G. Nicolás, M. López-Climent, A. Gómez-Cadenas, and C. Nicolás. 2009. Evidence for a role of gibberellins in salicylic acid-modulated early plant responses to abiotic stress in Arabidopsis seeds. Plant Physiol. 150:13351344, https://doi.org/10.1104/pp.109.139352.

Baldwin, E., A. Plotto, J. Manthey, G. Mccollum, J. Bai, M. Irey, R. Cameron, and G. Luzio. 2010. Effect of liberibacter infection (Huanglongbing disease) of citrus on orange fruit physiology and fruit/fruit juice quality: Chemical and physical analyses. J. Agr. Food Chem. 58:1247-1262, https://doi.org/10.1021/jf9031958.

Bassanezi, R.B., L.H. Montesino, M.C.G. Gasparoto, A.B. Filho, and L. Amorim. 2011. Yield loss caused by huanglongbing in different sweet orange cultivars in São Paulo, Brazil. Eur. J. Plant Pathol. 130:577-586, https://doi. org/10.1007/s10658-011-9779-1.

Bove, J. 2006. Huanglongbing: A destructive, newly-emerging, century-old disease of citrus. J. Plant Pathol. 88:7-37, https://doi.org/10.4454/ jpp.v88i1.828.

Chen, H.Q., K.L. Dekkers, L. Cao, J.K. Burns, L.W. Timmer, and K.R. Chung. 2006. Evaluation of growth regulator inhibitors for controlling postbloom fruit drop (PFD) of citrus induced by the fungus Colletotrichum acutatum. HortScience 41:1317-1321, https://doi. org/10.21273/HORTSCI.41.5.1317.

El-Zeftawi, B.M. 1980. Regulating pre-harvest fruit drop and the duration of the harvest season of grapefruit with 2,4-D and GA. J. Hort. Sci. 55:211-217, https://doi.org/10.1080/00221589. 1980.11514925

Estornell, L.H., J. Agustí, P. Merelo, M. Talón, and F.R. Tadeo. 2013. Elucidating mechanisms underlying organ abscission. Plant Sci. 199200:48-60, https://doi.org/10.1016/j.plantsci.2012. 10.008 .

Ferguson, L. and E.E. Grafton-Cardwell. 2014. Citrus production manual. Univ. California, Agr. Natural Resources, Oakland, CA

Fu, S., J. Shao, C. Zhou, and J.S. Hartung. 2016. Transcriptome analysis of sweet orange trees infected with "Candidatus Liberibacter asiaticus" and two strains of Citrus Tristeza Virus. BMC Genomics 17:1-18, https://doi.org/ 10.1186/s12864-016-2663-9.

García-Martínez, J.L. and M.A. García-Papí. 1979. The influence of gibberellic acid, 2,4-dichlorophenoxyacetic acid and 6-benzylaminopurine on fruit-set of Clementine mandarin. Scientia Hort. 10:285-293, https://doi.org/10.1016/03044238(79)90084-0.

Goldberg-Moeller, R., L. Shalom, L. Shlizerman, S. Samuels, N. Zur, R. Ophir, E. Blumwald, and A. Sadka. 2013. Effects of gibberellin treatment during flowering induction period on global gene expression and the transcription of flowering-control genes in Citrus buds. Plant Sci. 198: 46-57, https://doi.org/10.1016/j.plantsci.2012.09. 012 .

Gottwald, T. 2010. Current epidemiological understanding of citrus huanglongbing. Annu. Rev.
Phytopathol. 48:119-139, https://doi.org/10.1146/ annurev-phyto-073009-114418.

Graham, J.H., E.G. Johnson, T.R. Gottwald, and M.S. Irey. 2013. Presymptomatic fibrous root decline in citrus trees caused by Huanglongbing and potential interaction with Phytophthora spp. Plant Dis. 97:1195-1199, https://doi.org/ 10.1094/pdis-01-13-0024-re.

Guardiola, J.L., F. García-Marí, and M. Agustí. 1984. Competition and fruit set in the Washington navel orange. Physiol. Plant. 62:297-302, https://doi. org/10.1111/j.1399-3054.1984.tb04576.x.

Guardiola, J.L. 1988. Factors limiting productivity in Citrus. A physiological approach. Citriculture. Proceedings of the Sixth International Citrus Congress: Middle-East, Tel Aviv, Israel, 6-11 Mar. 1988.

Guardiola, J.L. and A. García-Luis. 2000. Increasing fruit size in citrus. Thinning and stimulation of fruit growth. Plant Growth Regulat. 31:121-132, https://doi.org/10.1023/A:1006339721880.

Hamido, S.A., K.T. Morgan, and D.M. Kadyampakeni. 2017. The effect of Huanglongbing on young citrus tree water use. HortTechnology 27:659-665, https://doi.org/10.21273/HORTTECH03830-17.

Hartmond, U., R. Yuan, J.K. Burns, A. Grant, and W.J. Kender. 2000. Citrus fruit abscission induced by methyl-jasmonate. J. Amer. Soc. Hort. Sci. 125:547-552, https://doi.org/10.21273/JASHS. 125.5.547

Hedden, P. and A.L. Phillips. 2000. Gibberellin metabolism: New insights revealed by the genes. Trends Plant Sci. 5:523-530, https://doi. org/10.1016/S1360-1385(00)01790-8.

Hellemans, J., G. Mortier, A. De Paepe, F. Speleman, and J. Vandesompele. 2007. qBase relative quantification framework and software for management and automated analysis of realtime quantitative PCR data. Genome Biol. 8:R19, https://doi.org/10.1186/gb-2007-8-2-r19. Iglesias, D.J., M. Cercós, J.M. Colmenero-Flores, M.A. Naranjo, G. Ríos, E. Carrera, O. RuizRivero, I. Lliso, R. Morillon, F.R. Tadeo, and M. Talon. 2007. Physiology of citrus fruiting. Braz. J. Plant Physiol. 19:333-362, https://doi. org/10.1590/S1677-04202007000400006.

Iqbal, N., R. Nazar, M.I.R. Khan, A. Masood, and N.A. Khan. 2011. Role of gibberellins in regulation of source-sink relations under optimal and limiting environmental conditions. Cur. Sci. 100:998-1007, http://www.jstor.org/stable/24076517.

Jahn, O.L. 1973. Inflorescence types and fruiting patterns in Hamlin and Valencia oranges and Marsh grapefruit. Amer. J. Bot. 60:663-670.

Johnson, E.G., J. Wu, D.B. Bright, and J.H. Graham. 2014. Association of 'Candidatus Liberibacter asiaticus' root infection, but not phloem plugging with root loss on Huanglongbingaffected trees prior to appearance of foliar symptoms. Plant Pathol. 63:290-298, https:// doi.org/10.1111/ppa.12109.

Kim, J. 2014. Four shades of detachment: Regulation of floral organ abscission. Plant signal. Beh. 9(11):e976154.

Killiny, N. and Y. Nehela. 2017. Metabolomic response to Huanglongbing: Role of carboxylic compounds in Citrus sinensis response to 'Candidatus Liberibacter asiaticus' and its vector, Diaphorina citri. Mol. Plant Microbe Interact. 30:666-678, https://doi.org/10.1094/mpmi05-17-0106-r.

Lord, E.M. and K.J. Eckard. 1987. Shoot development in Citrus sinensis L. (Washington navel orange). II. Alteration of developmental fate of flowering shoots after $\mathrm{GA}_{3}$ treatment. Bot. Gaz. 148:17-22, https://doi.org/10.1086/337623.

Mafra, V., K.S. Kubo, M. Alves-Ferreira, M. Ribeiro-Alves, R.M. Stuart, L.P. Boava, C.M 
Rodrigues, and M.A. Machado. 2012. Reference genes for accurate transcript normalization in citrus genotypes under different experimental conditions. PLoS One 7:e31263, https://doi. org/10.1371/journal.pone.0031263.

Malladi, A. and J.K. Burns. 2008. CsPLD $\alpha 1$ and CsPLD $\gamma 1$ are differentially induced during leaf and fruit abscission and diurnally regulated in Citrus sinensis. J. Expt. Bot. 59:3729-3739, https://doi.org/10.1093/jxb/ern224.

Martinelli, F., R.L. Reagan, S.L. Uratsu, M.L. Phu, U. Albrecht, W. Zhao, C.E. Davis, K.D. Bowman, and A.M. Dandekar. 2013. Gene regulatory networks elucidating huanglongbing disease mechanisms. PLoS One 8(9):e74256, https://doi. org/10.1371/journal.pone.0074256.

Martinelli, F., S.L. Uratsu, U. Albrecht, R.L. Reagan, M.L. Phu, M. Britton, V. Buffalo, J. Fass, E. Leicht, W. Zhao, D. Lin, R. D'Souza, C.E. Davis, K.D. Bowman, and A.M. Dandekar. 2012. Transcriptome profiling of citrus fruit response to huanglongbing disease. PLoS One 7(5): e38039, https://doi.org/10.1371/journal.pone.003 8039.

Miyamoto, K., M. Oka, and J. Ueda. 1997. Update on the possible mode of action of the jasmonates: Focus on the metabolism of cell wall polysaccharides in relation to growth and development. Physiol. Plant. 100:631-638, https://doi.org/ 10.1111/j.1399-3054.1997.tb03069.x.

Moss, G. I., B. T. Steer, and P. E. Kriedemann. 1972. The regulatory role of inflorescence leaves in fruit-setting by sweet orange (Citrus sinensis). Physiol. Planta. 27: 432-438.

Muñoz-Fambuena, N., C. Mesejo, M.C. GonzálezMas, D.J. Iglesias, E. Primo-Millo, and M. Agustí. 2012. Gibberellic acid reduces flowering intensity in sweet orange [Citrus sinensis (L.) Osbeck] by repressing CiFT gene expression. J. Plant Growth Regul. 31:529-536, https://doi.org/10.1007/s00344-012-9263-y.

Navarro, L., R. Bari, P. Achard, P. Lisón, A. Nemri, N.P. Harberd, and J.D.G. Jones. 2008. DELLAs control plant immune responses by modulating the balance of jasmonic acid and salicylic acid signaling. Curr. Biol. 18:650-655, https://doi. org/10.1016/j.cub.2008.03.060.

Nehela, Y., F. Hijaz, A.A. Elzaawely, H.M. ElZahaby, and N. Killiny. 2018. Citrus phytohormonal response to Candidatus Liberibacter asiaticus and its vector Diaphorina citri. Physiol. Mol. Plant Pathol. 102:24-35, https:// doi.org/10.1016/j.pmpp.2017.11.004.

Patterson, S.E. 2001. Cutting loose. Abscission and dehiscence in Arabidopsis. Plant Physiol. 126(2): 494-500, https://doi.org/10.1104/pp.126.2.494.

Pfaffl, M. 2001. A new mathematical model for relative quantification in real-time RT-PCR. Nucleic Acids Res. 29:e45, https://doi.org/ 10.1093/nar/29.9.e45.

Phillips, A.L., D.A. Ward, S. Uknes, N.E.J. Appleford, T. Lange, A.K. Huttly, P. Gaskin, J.E. Graebe, and P. Hedden. 1995. Isolation and expression of three gibberellin 20-oxidase cDNA clones from Arabidopsis. Plant Physiol. 108: 1049-1057, https://doi.org/10.1104\%2Fpp.108. 3.1049 .

Pitino, M., C.M. Armstrong, and Y. Duan. 2017. Molecular mechanisms behind the accumulation of ATP and $\mathrm{H}_{2} \mathrm{O}_{2}$ in citrus plants in response to "Candidatus Liberibacter asiaticus" infection. Hort. Res. 4:1-8, https://doi. org/10.1038/hortres.2017.40.

Rio, D.C. 2015. Denaturation and electrophoresis of RNA with formaldehyde. Cold Spring Harb. Protoc. 2015:306-313, https://doi.org/10.1101/ pdb.prot080994.

Rosales, R. and J.K. Burns. 2011. Phytohormone changes and carbohydrate status in sweet orange fruit from Huanglongbing-infected trees. J. Plant Growth Regul. 30:312-321.

Sachs, R.M., C. Bretz, and A. Lang. 1959. Cell division and gibberellic acid. Exp. Cell Res. 18:230-244, https://doi.org/10.1016/0014-4827 (59)90003-5.

Shokrollah, H., T.L. Abdullah, K. Sijam, and S.N.A. Abdullah. 2011. Identification of physical and biochemical characteristic of mandarin (Citrus reticulata) fruit infected by Huanglongbing (HLB). Aust. J. Crop Sci. 5:181-186.

Spreen, T.H., J.P. Baldwin, and S.H. Futch. 2014 An economic assessment of the impact of Huanglongbing on citrus tree plantings in Florida. HortScience 49:1052-1055, https://doi. org/10.21273/HORTSCI.49.8.1052.

Tang, L., S. Chhajed, and T. Vashisth. 2019. Preharvest fruit drop in huanglongbing-affected 'Valencia' sweet orange. J. Amer. Soc. Hort.
Sci. 144:107-117, https://doi.org/10.21273/JASHS 04625-18.

Tang, L. and C.J. Lovatt. 2019. Effects of low temperature and gibberellic acid on floral gene expression and floral determinacy in 'Washington' navel orange (Citrus sinensis L. Osbeck). Scientia Hort. 243:92-100, https://doi.org/10.1016/j.scienta. 2018.08.008.

Tang, L., G. Singh, M. Dewdney, and T. Vashisth. 2021. Effects of exogenous gibberellic acid in Huanglongbing-affected sweet orange trees under Florida conditions-I. Flower bud emergence and flower formation. HortScience 56: 1531-1541, https://doi.org/10.21273/HORTSCI 16080-21.

Tang, L., S. Singh, and T. Vashisth. 2020. Association between fruit development and mature fruit drop in Huanglongbing-affected sweet orange. HortScience 55:851-857, https://doi. org/10.21273/HORTSCI14931-20.

Tang, L. and T. Vashisth. 2020. New insight in Huanglongbing-associated mature fruit drop in citrus and its link to oxidative stress. Scientia Hort. 265:109246, https://doi.org/10.1016/j.scienta. 2020.109246.

Turnbull, C.G.N. 1989. Gibberellins and control of fruit retention and seedlessness in valencia orange. Acta Hort. 335-340, https://doi.org/ 10.17660/ActaHortic.1989.239.52.

U.S. Department of Agriculture. 2019. Florida citrus fruit size and drop 2018-19 report. U.S. Dept. Agr., Washington, DC.

Vashisth, T. and T. Livingston. 2020. Efficacy of infield thermotherapy in comparison and combination of defoliation for mitigating Huanglongbing in sweet orange. HortScience 55:251-257, https://doi.org/10.21273/HORTSCI14656-19.

Xia, Y., H. Suzuki, J. Borevitz, J. Blount, Z. Guo, K Patel, R.A. Dixon, and C. Lamb. 2004. An extracellular aspartic protease functions in Arabidopsis disease resistance signaling. EMBO J. 23:980 988, https://doi.org/10.1038/sj.emboj.7600086.

Zhao, W., E.A. Baldwin, J. Bai, A. Plotto, and M. Irey. 2019. Comparative analysis of the transcriptomes of the calyx abscission zone of sweet orange insights into the huanglongbingassociated fruit abscission. Hort. Res. 6, https:// doi.org/10.1038/s41438-019-0152-4. 
Supplemental Table 1. Gene-specific primer sequences for gene expression analysis in 'Valencia' sweet orange with quantitative real-time polymerase chain reaction.

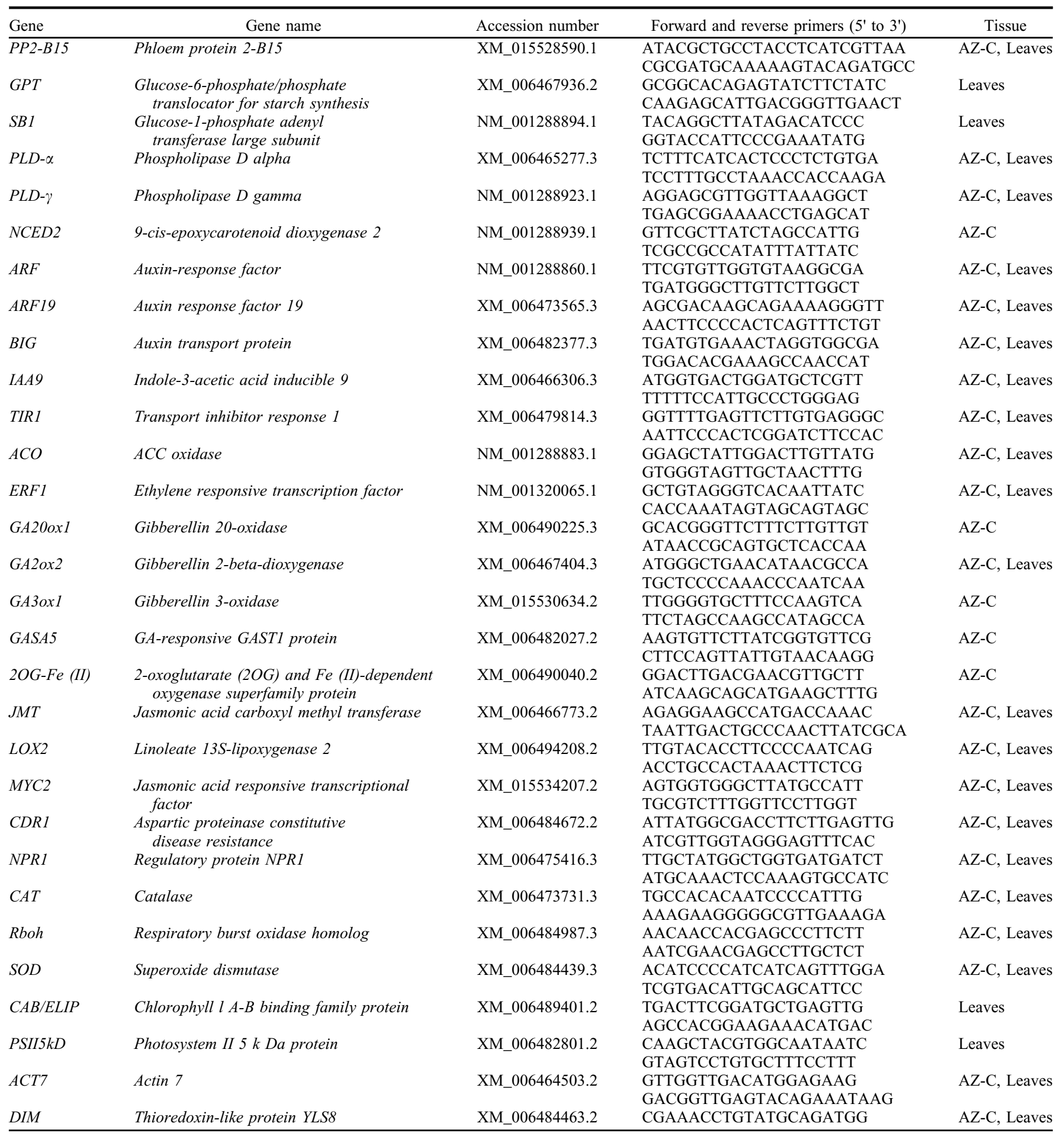


Supplemental Table 2. Expression [as log fold change (FC)] of selected genes in fruit abscission zone of untreated and gibberellic acid $\left(\mathrm{GA}_{3}\right)$ treated Huanglongbing-affected 'Valencia' sweet orange at time of harvest (May) in 2018-19.

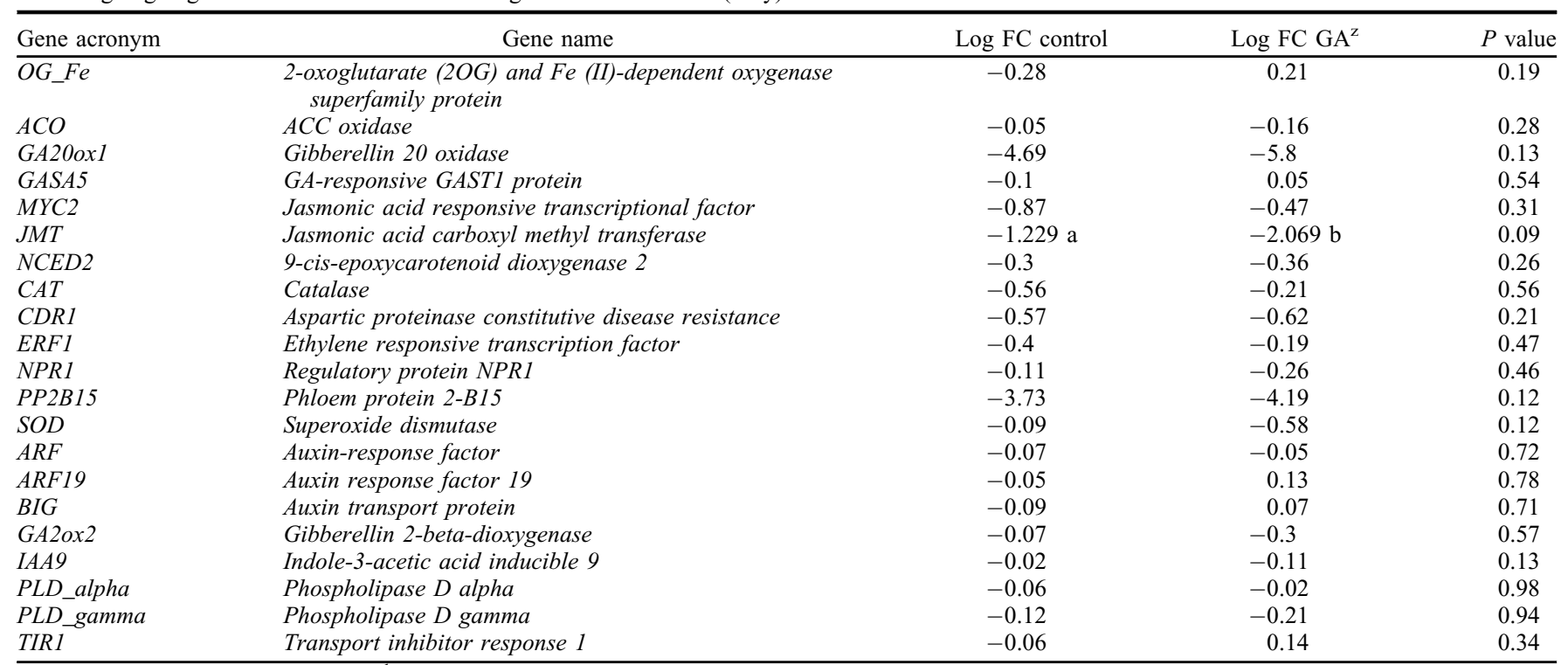

${ }^{\mathrm{z}}$ Gibberellic acid applied at $49 \mathrm{~g} \cdot \mathrm{ha}^{-1}$ monthly from September to January of each year with first application in 2016.

Supplemental Table 3. Expression [as log fold change $(\mathrm{FC})$ ] of selected genes in leaves of untreated and gibberellic acid $\left(\mathrm{GA}_{3}\right)$ treated Huanglongbingaffected 'Valencia' sweet orange at end of stage II of fruit development in 2018-19.

\begin{tabular}{|c|c|c|c|c|}
\hline & Gene name & Log FC control & $\log$ FC GA ${ }^{z}$ & $P$ value \\
\hline$\overline{A C O}$ & ACC oxidase & -0.27 & 0.00 & 0.86 \\
\hline CAB ELIP & Chlorophyll l $A-B$ binding family protein & -0.50 & 0.33 & 0.13 \\
\hline$C A T^{-}$ & Catalase & -0.55 & -0.25 & 0.3 \\
\hline$J M T$ & Jasmonic acid carboxyl methyl transferase & -0.28 & 0.21 & 0.78 \\
\hline MYC2 & Jasmonic acid responsive transcriptional factor & -0.35 & 0.06 & 0.62 \\
\hline NPRI & Regulatory protein NPRI & -0.13 & 0.15 & 0.27 \\
\hline$S O D$ & Superoxide dismutase & -0.01 & 0.04 & 0.68 \\
\hline$S B 1$ & Glucose-1-phosphate adenyl transferase large subunit & -0.22 & -0.11 & 0.76 \\
\hline ARF19 & Auxin response factor 19 & -0.21 & -0.17 & 0.98 \\
\hline GA2ox2 & Gibberellin 2-beta-dioxygenase & -0.21 & -0.39 & 0.92 \\
\hline IAA9 & Indole-3-acetic acid inducible 9 & -0.09 & 0.03 & 0.28 \\
\hline$A R F$ & Auxin-response factor & $-0.125 \mathrm{~b}$ & $-0.053 \mathrm{a}$ & 0.08 \\
\hline$B I G$ & Auxin transport protein & $-0.122 \mathrm{~b}$ & $-0.099 \mathrm{a}$ & 0.07 \\
\hline
\end{tabular}

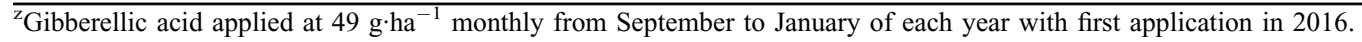

